\title{
Beban Pencemaran, Kapasitas Asimilasi dan Status Pencemaran Estuari Banjir Kanal Barat, Kota Semarang, Jawa Tengah
}

\section{Pollution Load, Assimilation Capacity And Pollution State of West Banjir Kanal Estuary, Semarang City, Central Java}

\author{
Haeruddina ${ }^{\mathrm{a}}$ Pujiono W. Purnomo ${ }^{\mathrm{b}}$, Sigit Febrianto ${ }^{\mathrm{c}}$ \\ a Program Studi Doktor Manajemen Sumberdaya Pantai, Departemen Sumberdaya Akuatik, Fakultas Perikanan dan Ilmu Kelautan, \\ Universitas Diponegoro. \\ ${ }^{\text {b }}$ Program Studi Magister Manajemen Sumberdaya Pantai, Departemen Sumberdaya Akuatik, Fakultas Perikanan dan Ilmu Kelautan, \\ Universitas Diponegoro. \\ c Program Studi Sarjana Manajemen Sumberdaya Perairan, Departemen Sumberdaya Akuatik, Fakultas Perikanan dan Ilmu \\ Kelautan, Universitas Diponegoro.
}

\section{Article Info:}

Received: 11 - 04 - 2018

Accepted: 04 - 04 - 2019

\section{Keywords:}

Assimilation capacity, pollution load, pollution state, $B K B$ estuary.

\section{Corresponding Author: Haeruddin \\ Program Studi Doktor \\ Manajemen Sumberdaya Pantai, \\ Departemen Sumberdaya \\ Akuatik, Fakultas Perikanan dan \\ Ilmu Kelautan, Universitas \\ Diponegoro; \\ Tel. +62-24-76404447 \\ Email: \\ haeruddindaengmile@gmail.com}

\begin{abstract}
West Banjir Kanal river is part of Garang Catchment Area which used as souce of drinking water for communities of West Semarang District, Central Java. The high intensities used of area around Garang Catchment Area for agriculture, settlement and industry caused water polluted. This research conducted to determine pollution loading, assimilation capacity and pollution state of west Banjir Kanal estuary. The research done by survey method with collected of water samples from 3 sampling point with 3 replication respectively. The result showed that pollution load was 22751.493 - $117256.591 \mathrm{~kg} /$ day TSS, 154.019 - $1843.323 \mathrm{~kg} /$ day nitrate and $0-835.463 \mathrm{~kg} /$ day phosphat, which these values have has exceeded their assimilation capacity, causing water pollution. Water Quality Index value is 51.94 and which indicates that West Banjir Kanal Estuary is very high polluted by TSS, nitrate and phosphate.
\end{abstract}

How to cite (CSE Style $8^{\text {th }}$ Edition):

Haeruddin, Purnomo PW, Febrianto S. 2019. Beban pencemaran, kapasitas asimilasi dan status pencemaran estuari Banjir Kanal Barat, Kota Semarang, Jawa Tengah. JPSL 9(3): 723-735. http://dx.doi.org/10.29244/jps1.9.3.723-735.

\section{PENDAHULUAN}

Estuaria merupakan wilayah pertemuan antara air tawar dan air laut, sehingga memiliki air yang bersifat payau (Ketchum 1983). Air sungai membawa berbagai bahan yang masuk ke dalamnya, dari hulu hingga hilir kemudian terakumulasi di estuari, sehingga berbagai bahan tersebut memiliki konsentrasi yang lebih tinggi di estuaria dibanding bagian sungai lainnya.

Sungai Banjir Kanal Barat (BKB) merupakan bagian dari DAS Garang. Lahan di sekitar DAS Garang dimanfaatkan untuk berbagai keperluan seperti pertanian, pemukiman dan industri (Dewi et al. 2014; Kementerian Kelautan dan Perikanan 2015). Semua kegiatan tersebut berpotensi menyebabkan gangguan terhadap ekosistem air sungai dikarenakan menurunkan kualitas air sungai. Pembukaan dan pengolahan lahan 
untuk kegiatan pertanian berpotensi meningkatkan erosi tanah dan meningkatkan konsentrasi TSS dalam air sungai (Owa 2014), disamping dapat meningkatkan konsentrasi nitrat dan fosfat dalam air yang berasal dari kegiatan pemupukan tanaman (Sun et al. 2012). Tim peneliti Kementerian Kelautan dan Perikanan (2015) menyatakan bahwa DAS Garang memiliki konsentrasi padatan tersuspensi total (TSS), nitrat, dan fosfat yang melampaui baku mutu air sungai. Padahal air sungai tersebut dimanfaatkan untuk bahan baku air minum bagi masyarakat Kecamatan Semarang Barat, Kota Semarang (Ujianti et al. 2018). Berdasarkan kondisi tersebut dilakukan penelitian untuk mengetahui beban pencemaran dan kapasitas asimilasi TSS, nitrat dan posfat pada muara sungai BKB. Konsentrasi TSS yang tinggi dalam air, menyebabkan air keruh dan mengganggu proses fotosintesis oleh alga serta sedimentasi (Ostroumov, 2014; Drewniak et al. 2015). Nitrat dan fosfat merupakan sumber nutrien bagi alga (Boyd and Tucker 2012) dan dapat meyebabkan eutrofikasi (Dodds and Smith 2016; Jiang et al. 2016).

Beban pencemaran didefinisikan sebagai banyaknya kandungan bahan pencemar dalam air (Peraturan Pemerintah (PP) Republik Indonesia Nomor 82 Tahun 2001). Pada PP yang sama, kapasitas asimilasi didefinisikan sebagai kemampuan suatu badan air untuk pulih diri (self purification) setelah kemasukan bahan pencemar. Beban pencemaran suatu badan air apabila melampaui kapasitas asimilasinya, akan menyebabkan pencemaran air.

Penelitian ini dilakukan dengan tujuan untuk menentukan besar beban pencemaran TSS, nitrat, dan fosfat muara sungai BKB serta menetapkan kapasitas asimilasi dan status pencemaran estuari BKB.

\section{METODE}

\section{Lokasi dan Waktu Penelitian}

Contoh air dikumpulkan dari muara sungai BKB pada bulan Juli 2018. Pada awal tahun 2000, curah hujan di kota Semarang terendah pada bulan Juli (Dinas PSDA 2002 dalam Supriyanto 2003), namun data curah dan hari hujan di Kota Semarang antara Tahun 2013 hingga 2017 menunjukkan bahwa curah dan hari hujan pada bulan Juli 2 kali lebih tinggi dari data curah dan hari hujan bulan September (BPS 2013; 2017; 2018).

Titik sampling sebanyak 3 (tiga) dan setiap titik diulang tiga kali. Letak titik sampling 1,2 dan 3 serta ulangannya disajikan pada sketsa Gambar 1.

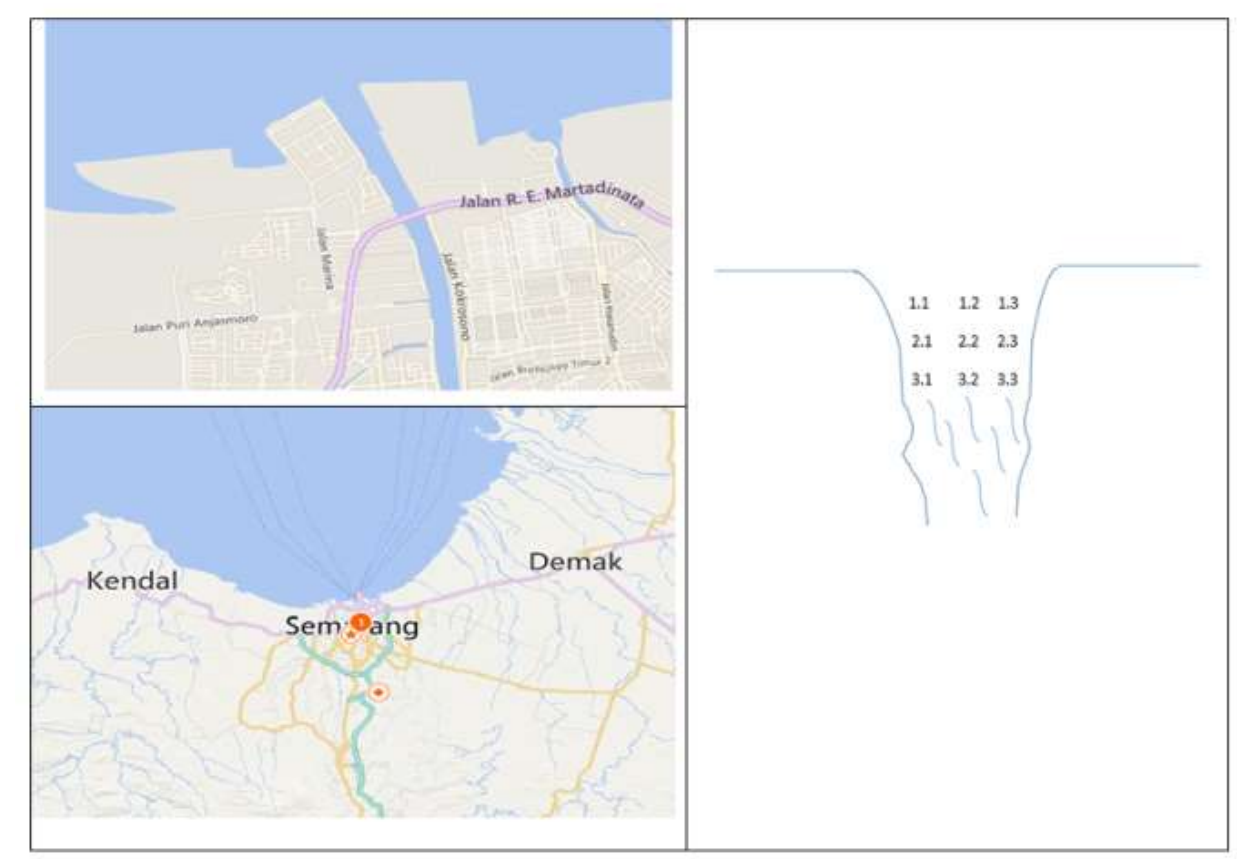

Gambar 1 Lokasi dan sketsa letak titik sampling. 


\section{Metode Pengumpulan Data}

Materi yang digunakan untuk penelitian adalah contoh air yang diperoleh dari muara sungai BKB. Pengambilan contoh air untuk keperluan analisis TSS, nitrat, dan fosfat dilakukan dengan menggunakan Van Dorn water sampler volume 2.2 liter. Contoh air yang diperoleh dimasukkan ke dalam botol contoh yang dapat menampung 2 liter contoh air. Semua contoh air yang diperoleh diangkut ke laboratorium untuk dianalisis. Selama proses pengangkutan dan penyimpanan, semua contoh air diinginkan dalam cooler box (selama pengangkutan) volume 16 liter dan freezer (selama penyimpanan). Analisis TSS dilakukan dengan metode gravimetri, analisis nitrat dan fosfat dengan metode spektrofotometri (APHA, 2012; SNI 1991, 2004, 2005).

\section{Metode Analisis Data}

\section{Beban Pencemaran}

Beban pencemaran ditentukan berdasarkan konsentrasi bahan pencemar yang terdapat di muara sungai dikalikan dengan debit rata-rata sungai tersebut pada saat studi dilakukan menggunakan persamaan (Mitsch and Gosselink, (1994) dan Lampiran II Peraturan Menteri Negara Lingkungan Hidup Nomor 1 Tahun 2010):

$$
\mathrm{BP}=\mathrm{Q} \times \mathrm{C} \times f
$$

Keterangan:

$\mathrm{BP}=$ beban pencemaran dari suatu muara sungai dalam $\mathrm{kg} / \mathrm{hari}$

$\mathrm{Q}=$ debit muara sungai dalam $\mathrm{m}^{3} /$ tahun

$\mathrm{C}=$ konsentrasi TSS, nitrat, posfat dan logam ( $\mathrm{mg} / \mathrm{l})$.

$f=$ faktor konversi $=86,4(\mathrm{~kg}$. lt.detik) $/(\mathrm{mg} . \mathrm{m} 3$.hari $)$

Data debit sungai diperoleh dengan pengukuran pada beberapa segmen sungai sebagaimana disajikan pada Gambar 2.

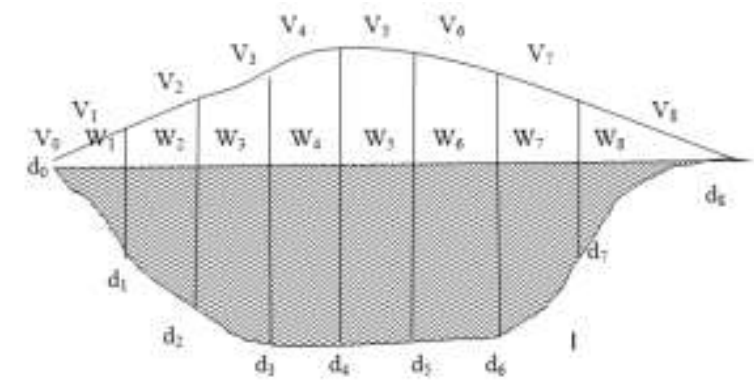

Gambar 2 Penampang melintang muara sungai untuk pengukuran debit badan air mengalir.

Debit air sungai diperoleh menggunakan persamaan (Purnomo et al. 2010) sebagai berikut:

$$
Q=W_{1} \frac{\left(d_{0}+d_{1}\right)}{2} x \frac{\left(v_{0}+v_{1}\right)}{2}+\ldots . .+W_{3} \frac{\left(d_{7}+d_{8}\right)}{2} x \frac{\left(v_{7}+v_{1}\right)}{2}
$$

$\mathrm{Q}=$ Debit air $\left(\mathrm{m}^{3} /\right.$ detik $)$

$\mathrm{W}_{1}$ hingga $\mathrm{W}_{8}=$ lebar segmen $(\mathrm{m})$

$\mathrm{d}=$ kedalaman $(\mathrm{m})$

$\mathrm{V}=$ kecepatan arus dalam tiap segmen $(\mathrm{m} /$ detik $)$ 


\section{Kapasitas Asimilasi}

Kapasitas asimilasi ditentukan dengan menggunakan metode yang diusulkan oleh Dahuri (1998) dengan menggunakan garis perpotongan antara baku mutu suatu unsur atau senyawa dengan garis regresi yang menghubungkan antara konsentrasi bahan pencemar sebagai sumbu X dengan beban pencemar sebagai sumbu Y.

\section{Indeks Kualitas Air}

Penetapan tingkat pencemaran perairan dilakukan berdasarkan Indeks Kualitas Air (IKA) dengan menggunakan persamaan Altansuukh dan Davaa (2011) sebagai berikut:

$$
\mathrm{IKA}=\frac{\sum \mathrm{C}_{\mathrm{i}} \cdot \mathrm{PI}_{\mathrm{i}}}{-----}
$$

$\mathrm{n}$

IKA : Indeks Kualitas Air

$\mathrm{C}_{\mathrm{i}} \quad$ : konsentrasi peubah mutu air ke-i

$\mathrm{PI}_{\mathrm{i}} \quad$ : baku mutu air yang diperbolehkan untuk peubah mutu air ke-i

$\mathrm{N} \quad$ : jumlah peubah mutu air yang diamati

Persamaan IKA tersebut diatas telah diuji coba dibandingkan dengan Indeks Pencemaran (IP) yang dikeluarkan oleh Kementerian Lingkungan Hidup Republik Indonesia dengan hasil bahwa IKA lebih mencerminkan kondisi lapangan dibanding IP (Marganingrum, 2012). Disamping itu IKA lebih sederhana dan mudah penerapannya dibanding IP, sehingga lebih dapat diaplikasikan untuk khalayak umum dibanding IP. Kriteria indeks kualitas air disajikan pada Tabel 1.

Tabel 1 Kriteria Indeks Kualitas Air (IKA).

\begin{tabular}{|c|c|c|c|}
\hline \multirow{2}{*}{ Nilai IKA } & \multicolumn{2}{|c|}{ Kualitas Air } & \multirow{2}{*}{ Rekomendasi } \\
\hline & Tingkat & Kelas & \\
\hline$\leq 0.3$ & 1 & Sangat Bersih & Layak untuk media hidup biota laut tanpa pengolahan \\
\hline $\begin{array}{l}0.3<\mathrm{IKA} \leq \\
0.89\end{array}$ & 2 & Bersih & $\begin{array}{l}\text { Layak untuk media hidup biota laut dengan } \\
\text { pengolahan terlebih dahulu }\end{array}$ \\
\hline $\begin{array}{l}0.89<\mathrm{IKA} \leq 2.4 \\
9\end{array}$ & 3 & Tercemar ringan & $\begin{array}{l}\text { Layak untuk media hidup biota laut dengan } \\
\text { pengolahan terlebih dahulu }\end{array}$ \\
\hline $\begin{array}{l}2.49<\mathrm{IKA} \leq 3.9 \\
9\end{array}$ & 4 & Tercemar sedang & $\begin{array}{l}\text { Tidak layak untuk media hidup biota laut, hanya sesuai } \\
\text { untuk industry dengan pengolahan }\end{array}$ \\
\hline $\begin{array}{l}3.99<\mathrm{IKA} \leq 5.9 \\
9\end{array}$ & 5 & Tercemar Berat & $\begin{array}{l}\text { Hanya dapat digunakan untuk industry dan tidak ada } \\
\text { kontak langsung dengan manusia }\end{array}$ \\
\hline$>5.99$ & 6 & $\begin{array}{l}\text { Kotor/Tercemar } \\
\text { sangat Berat }\end{array}$ & $\begin{array}{l}\text { Tidak sesuai untuk berbagai kebutuhan dan butuh } \\
\text { biaya yang sangat mahal untuk pemanfaatan }\end{array}$ \\
\hline
\end{tabular}

Sumber: Modifikasi dari Marganingrum (2012).

\section{HASIL DAN PEMBAHASAN}

\section{Hasil}

\section{Konsentrasi TSS, Nitrat dan Fosfat}

Setelah dilakukan sampling diperoleh data konsentrasi TSS, nitrat dan fosfat air sungai sebagaimana disajikan pada Tabel 2. Tabel 2 menunjukkan bahwa konsentrasi TSS dan nitrat terendah pada titik sampling 
1 dan konsentrasi fosfat terendah pada titik sampling 2. Konsentrasi TSS terendah pada 2 titik yang terletak di tengah-tengah muara sungai dan tertingi pada tepi kanan muara sungai (bagian timur). Sementara untuk nitrat dan fosfat, konsentrasi terendah umumnya terdapat di tepi sungai bagian barat. Konsentrasi TSS, nitrat dan fosfat tertinggi pada titik sampling 3. Konsentrasi TSS, nitrat dan fosfat yang terukur kesemuanya melampaui baku mutu air laut untuk biota laut.

Tabel 2 Konsentrasi TSS (mg/l), nitrat (mg/l), dan fosfat (mg/l).

\begin{tabular}{llrrr}
\hline \multirow{2}{*}{ Titik Sampling } & Ulangan & \multicolumn{3}{c}{ Peubah mutu air } \\
\cline { 3 - 5 } & & TSS $(\mathrm{mg} / \mathrm{l})$ & $\begin{array}{r}\text { Nitrat } \\
(\mathrm{mg} / \mathrm{l})\end{array}$ & Fosfat (mg/l) \\
\hline I. & 1 & 88.42 & 0.48 & 0.00 \\
& 2 & 86.20 & 1.39 & 0.31 \\
& 3 & 86.80 & 1.30 & 0.63 \\
\cline { 2 - 5 } & Rataan & 87.14 & 1.06 & 0.31 \\
& SD & 1.15 & 0.50 & 0.32 \\
\hline II. & 1 & 93.33 & 1.32 & 0.60 \\
& 2 & 90.28 & 1.01 & 0.11 \\
& 3 & 92.46 & 0.87 & 0.02 \\
\cline { 2 - 5 } & Rataan & 92.02 & 1.07 & 0.24 \\
& SD & 1.57 & 0.23 & 0.31 \\
\hline III. & 1 & 105.33 & 1.41 & 0.37 \\
& 2 & 106.72 & 1.22 & 0.49 \\
& 3 & 104.88 & 0.71 & 0.14 \\
\cline { 2 - 5 } & Rataan & 105.64 & 1.11 & 0.33 \\
& SD & 0.96 & 0.36 & 0.18 \\
\hline
\end{tabular}

Hasil analisis ragam menunjukkan bahwa konsentrasi TSS sangat berbeda nyata antara stasiun $(p=0.00)$, konsentrasi nitrat tidak berbeda nyata $(\mathrm{p}=0.981)$ antar stasiun demikian juga konsentrasi fosfat tidak berbeda nyata $(\mathrm{p}=0.917)$ antara stasiun.

\section{Lebar, kedalaman dan kecepatan aliran}

Hasil pengukuran kedalaman sungai menunjukkan bahwa bagian terdalam terdapat pada titik sampling 1 dan terdangkal pada titik sampling 3. Ada kecenderungan bagian sungai lebih dalam pada sisi bagian barat, Analisis ragam menunjukkan bahwa kedalaman sungai antar titik pengambilan contoh air relatif tidak berbeda nyata $(\mathrm{p}=0,581)$.

Kecepatan arus yang terukur paling cepat di titik sampling 1 dan terlambat pada titik sampling 3. Ada kecenderungan bahwa aliran sungai pada titik sampling I lebih kencang pada bagian tengah ke arah barat, pada tititk sampling 2 lebih kencang di bagian tengah ke tepi timur sungai dan pada titik sampling 3 lebih kencang di bagian barat sungai, Analisis ragam menunjukkan bahwa kecepatan aliran sungai antar titik pengambilan contoh air sangat berbeda nyata $(\mathrm{p}=0)$. Data kedalaman dan kecepatan aliran air sungai disajikan pada Tabel 3 . 
Tabel 3 Lebar segmen (w), kedalaman (d) dan kecepatan aliran sungai (v) pada berbagai segmen sungai $\mathrm{BKB}$

\begin{tabular}{|c|c|c|c|c|}
\hline \multirow[b]{2}{*}{ Titik } & \multirow[b]{2}{*}{ Segmen } & \multicolumn{3}{|c|}{ Peubah mutu air } \\
\hline & & $\begin{array}{l}\text { Lebar } \\
\text { (m) }\end{array}$ & $\operatorname{Kedlman}(\mathrm{cm})$ & $\begin{array}{l}\text { Kec. arus } \\
(\mathrm{m} / \mathrm{s})\end{array}$ \\
\hline \multirow[t]{10}{*}{ I. } & 1 & 30 & 70 & 0.08 \\
\hline & 2 & 30 & 90 & 0.08 \\
\hline & 3 & 30 & 70 & 0.08 \\
\hline & 4 & 30 & 60 & 0.10 \\
\hline & 5 & 30 & 60 & 0.10 \\
\hline & 6 & 30 & 70 & 0.13 \\
\hline & 7 & 30 & 90 & 0.13 \\
\hline & 8 & 30 & 70 & 0.06 \\
\hline & Rataan & 30 & 72.50 & 0.08 \\
\hline & SD & 0 & 11.65 & 0.01 \\
\hline \multirow[t]{10}{*}{ II. } & 1 & 20 & 55 & 0.08 \\
\hline & 2 & 20 & 68 & 0.08 \\
\hline & 3 & 20 & 50 & 0.08 \\
\hline & 4 & 30 & 47 & 0.09 \\
\hline & 5 & 30 & 90 & 0.09 \\
\hline & 6 & 20 & 70 & 0.06 \\
\hline & 7 & 20 & 70 & 0.06 \\
\hline & 8 & 20 & 73 & 0.06 \\
\hline & Rataan & 22.50 & 65.38 & 0.08 \\
\hline & SD & 4.63 & 14.12 & 0.01 \\
\hline \multirow[t]{10}{*}{ III. } & 1 & 10 & 58 & 0.01 \\
\hline & 2 & 10 & 45 & 0.01 \\
\hline & 3 & 10 & 68 & 0.01 \\
\hline & 4 & 10 & 75 & 0.01 \\
\hline & 5 & 10 & 90 & 0.01 \\
\hline & 6 & 10 & 80 & 0.07 \\
\hline & 7 & 10 & 75 & 0.07 \\
\hline & 8 & 10 & 55 & 0.08 \\
\hline & Rataan & 10.00 & 68.25 & 0.03 \\
\hline & SD & 0.00 & 14.75 & 0.03 \\
\hline
\end{tabular}

Hasil Analisis Komponen Principal (Principal Component Analysis) konsentrasi TSS, nitrat dan fosfat terhadap kedalaman dan kecepatan arus muara sungai BKB menunjukkan hasil sebagaimana Gambar 3. Konsentrasi TSS memiliki kedekatan hubungan dengan kecepatan arus, sementara konsentrasi nitrat dan fosfat lebih berkaitan dengan kedalaman sungai BKB. Hasil analisis regresi korelasi menunjukkan bahwa konsentrasi TSS memiliki hubungan yang cukup erat dengan kecepatan arus sungai namun tidak erat dengan kedalaman air sungai. Konsentrasi nitrat dan fosfat tidak berhubungan erat dengan kecepatan arus namun ada hubungan dengan kedalaman air sungai. 


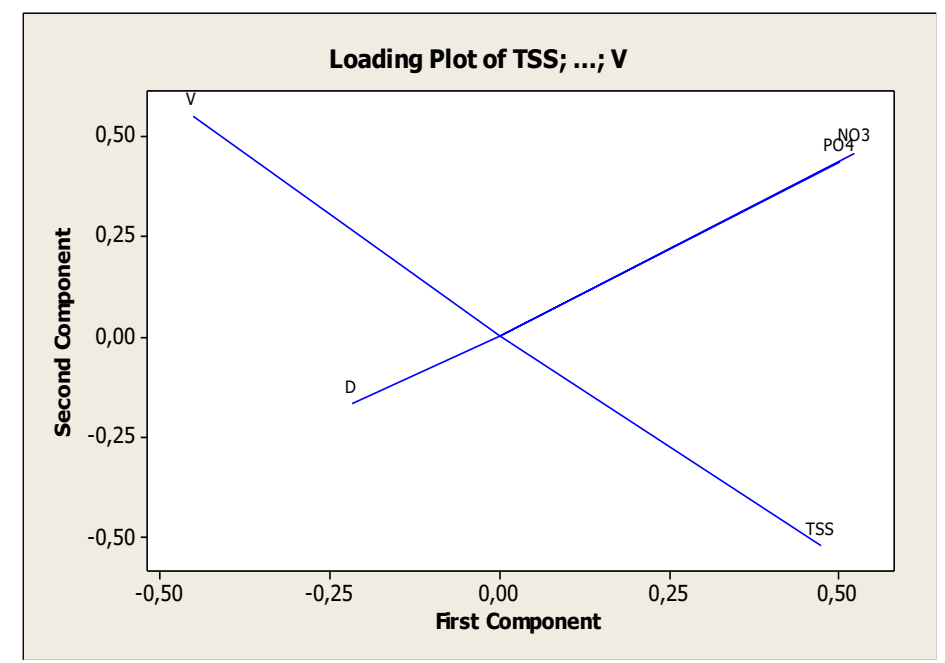

Gambar 3 Loading plot TSS, nitrat, fosfat terhadap kedalaman dan kecepatan arus sungai BKB.

\section{Temperatur, $\mathrm{pH}$, salinitas dan oksigen terlarut}

Tabel 4 menunjukkan bahwa temperatur titik sampling berkisar $30.96-31.43^{\circ} \mathrm{C}$. Temperatur air sungai tertinggi diukur pada titik sampling 1 dan temperatur terendah terukur pada titik sampling 3. pH berkisar 7.68 -7.78. $\mathrm{pH}$ tertinggi diukur pada pada titik sampling 1 dan $\mathrm{pH}$ terendah terukur pada titik sampling 3 . Salinitas berkisar $12-16$ ppt, salinitas terendah terukur pada titik sampling 2 dan salinitas tertinggi terukur pada titik sampling 1. Konsentrasi oksigen terlarut berkisar $5.34-5.94$, konsentrasi oksigen terendah terukur pada titik sampling 1 dan tertinggi pada titik sampling 2.

Salinitas air pada estuaria BKB berkisar 12 - 16 ppt, sehingga baku mutu yang digunakan dalam perhitungan kapasitas asimilasi dan indeks kualitas air adalah Baku Mutu Air Laut (Keputusan Menteri Negara LH No 51Tahun 2004 tentang Baku Mutu Air Laut untuk biota laut).

Tabel 4 Temperatur, $\mathrm{pH}$, salinitas dan oksigen terlarut di lokasi penelitian.

\begin{tabular}{lccccc}
\hline \multirow{2}{*}{ Titik } & \multirow{2}{*}{ Ulangan } & \multicolumn{4}{c}{ Peubah mutu air } \\
\cline { 3 - 6 } & & Temp. $\left({ }^{\circ} \mathrm{C}\right)$ & $\mathrm{pH}$ & Salinitas $(\mathrm{o} / \mathrm{oo})$ & $\mathrm{DO}(\mathrm{mg} / \mathrm{l})$ \\
\hline I. & 1 & 30.43 & 7.78 & 20 & 5.34 \\
& 2 & 30.38 & 7.72 & 30 & 5.42 \\
& 3 & 30.4 & 7.7 & 16 & 5.56 \\
\cline { 2 - 6 } & Rataan & 30.40 & 7.73 & 22.00 & 5.44 \\
II. & SD & 0.03 & 0.04 & 7.21 & 0.11 \\
& 1 & 30.2 & 7.72 & 20 & 5.94 \\
& 2 & 30.18 & 7.76 & 20 & 5.78 \\
& 3 & 29.98 & 7.74 & 15 & 5.88 \\
\cline { 2 - 6 } & Rataan & 30.12 & 7.74 & 18.33 & 5.87 \\
III. & SD & 0.12 & 0.02 & 2.89 & 0.08 \\
& 1 & 30.3 & 7.76 & 15 & 5.68 \\
& 2 & 29.96 & 7.68 & 20 & 5.7 \\
& 3 & 30.18 & 7.74 & 15 & 5.66 \\
\hline & Rataan & 30.15 & 7.73 & 16.67 & 5.68 \\
& SD & 0.17 & 0.04 & 2.89 & 0.02 \\
\hline
\end{tabular}

\section{Beban Pencemaran Sungai Banjir Kanal Barat}

Berdasarkan data konsentrasi TSS, nitrat dan fosfat serta debit air sungai, diperoleh beban pencemaran dari muara sungai BKB sebagaimana disajikan pada Tabel 5. Beban pencemaran sungai BKB semakin meningkat ke arah muara. Beban pencemaran terendah pada titik sampling paling atas ke arah hulu dan tertinggi di muara sungai. Hal ini disebabkan lebar sungai ke arah muara semakin lebar, Pada titik sampling 
3, lebar sungai 80 meter, titik sampling 2 lebar sungai sebesar $180 \mathrm{~m}$ dan pada titik sampling 1 lebar sungai mencapai 240 meter. Kedalaman dan kecepatan arus sungai pada titik sampling 1 dan 2, relatif hampir sama, kecuali pada titik sampling 3, kecepatan arus lebih rendah, terutama pada sungai sisi timur. Hasil analisis ragam menunjukkan bahwa kedalaman sungai antara titik pengambilan contoh air relatif sama atau tidak berbeda nyata, namun arus sangat berbeda nyata.

Tabel 5 Beban pencemaran (ton/tahun) TSS, nitrat dan fosfat sungai Banjir Kanal Barat.

\begin{tabular}{llrrr}
\hline Tttik & \multicolumn{3}{c}{ Ulangan } & \multicolumn{2}{c}{ TSS } & Nitrat & \multicolumn{2}{c}{ Fosfat } \\
\cline { 3 - 5 } & & 117256.591 & 636.543 & 0.000 \\
\hline I. & 1 & 114312.578 & 1843.323 & 411.101 \\
& 2 & 115108.258 & 1723.972 & 835.463 \\
\cline { 2 - 5 } & Rataan & 115559.142 & 1401.279 & 415.521 \\
& SD & 1522.917 & 664.964 & 417.749 \\
\cline { 2 - 5 } II. & 1 & 95984.380 & 1357.542 & 617.064 \\
& 2 & 92847.635 & 1038.725 & 113.128 \\
& 3 & 95089.636 & 894.743 & 20.569 \\
\hline & Rataan & 94640.550 & 1097.003 & 250.254 \\
& SD & 1615.875 & 236.840 & 321.020 \\
\hline III & 1 & 22849.111 & 305.870 & 80.264 \\
& 2 & 23150.642 & 264.653 & 106.295 \\
& 3 & 22751.493 & 154.019 & 30.370 \\
\hline & Rataan & 22917.082 & 241.514 & 72.310 \\
& SD & 208.075 & 78.525 & 38.582 \\
\hline
\end{tabular}

\section{Kapasitas Asimilasi}

Merujuk data pada Tabel 5 dilakukan analisis regresi untuk menentukan kapasitas asimilasi (Dahuri, 1998) untuk masing-masing variabel TSS, nitrat dan fosfat, sehingga diperoleh hasil sebagai berikut:

- Persamaan regresi antara konsentrasi TSS (mg/l) dengan beban pencemaran TSS (kg/hari) sungai BKB adalah $\mathrm{y}=778.8 \mathrm{x}\left(\mathrm{R}^{2}=-0.339\right)$, sehingga kapasitas asimilasi TSS sebesar: $15.576 \mathrm{~kg}$ hari untuk terumbu karang (Baku mutu $=20 \mathrm{mg} / \mathrm{l}$ ) dan $62.304 \mathrm{~kg} /$ hari untuk mangrove (baku mutu $=20 \mathrm{mg} / \mathrm{l}$ ),

- Persamaan regresi antara konsentrasi nitrat $(\mathrm{mg} / \mathrm{l})$ dengan beban pencemaran nitrat $(\mathrm{kg} / \mathrm{hari})$ sungai BKB adalah y $=844.92 x\left(\mathrm{R}^{2}=0.1881\right)$. sehingga kapasitas asimilasi TSS sebesar: $6.759 \mathrm{~kg}$ hari (baku mutu $=0.008 \mathrm{mg} / \mathrm{l}$ nitrat $)$,

- Persamaan regresi antara konsentrasi nitrat $(\mathrm{mg} / \mathrm{l})$ dengan beban pencemaran fosfat adalah $\mathrm{y}=889.72 \mathrm{x}$ $\left(\mathrm{R}^{2}=0.618\right.$ ). sehingga kapasitas asimilasi fosfat sebesar $13.346 \mathrm{~kg} / \mathrm{hari}$ (baku mutu $=0.015 \mathrm{mg} / \mathrm{l}$ fosfat.

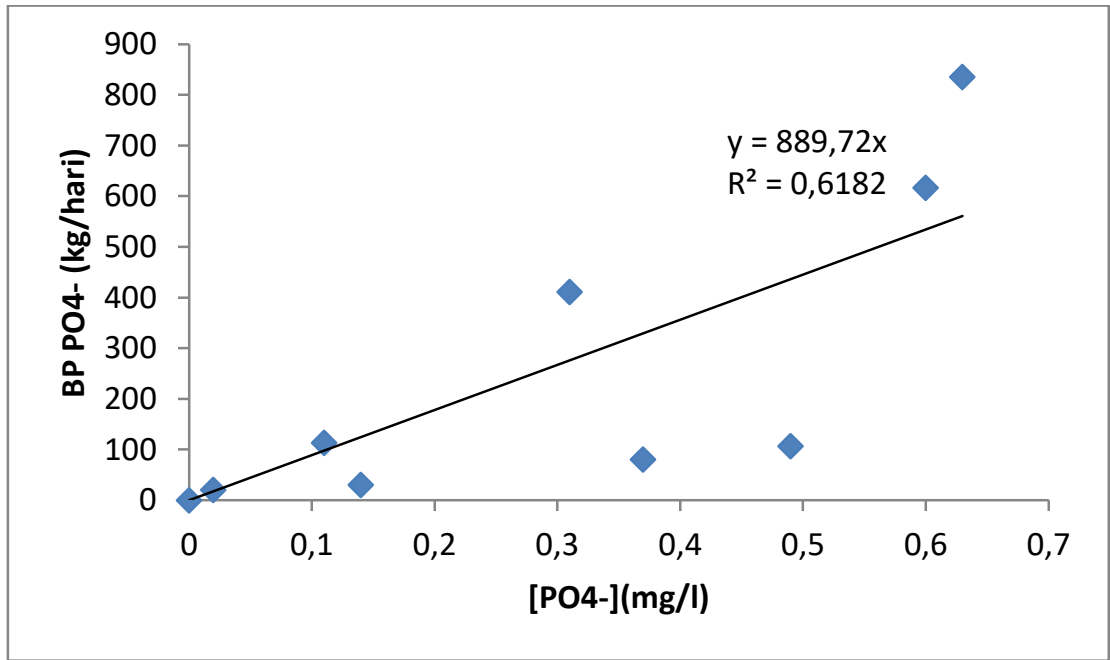

Gambar 4 Hubungan konsentrasi fosfat dan beban pencemaran fosfat di muara sungai BKB. 


\section{Indeks Kualitas Air}

Hasil perhitungan indeks kualitas air (IKA) diperoleh nilai IKA sebesar 51,94 atau tergolong air dengan kelas tercemar sangat berat atau kotor atau berada pada peringkat 6 menurut klasifikasi kualitas air Marganingrum (2012) setelah dimodifikasi.

\section{Pembahasan}

Konsentrasi TSS, nitrat dan fosfat di muara sungai yang melampaui baku mutu air laut untuk biota laut diduga berasal dari kegiatan pertanian dan pemukiman yang terdapat di sekitar daerah aliran sungai Garang sebagai induk dari sungai BKB. DAS Garang membentang dari $110^{\circ} 18^{\prime} 28^{\prime \prime}$ BT sampai $110^{\circ} 25^{\prime} 59^{\prime \prime}$ BT dan antara $6^{\circ} 56^{\prime} 46^{\prime \prime}$ LS sampai dengan $7^{\circ} 11^{\prime} 47^{\prime \prime}$ LS dengan luas keseluruhan DAS Garang adalah 21447.15 Ha (Ujiati et al. 2018). Sebagian besar lahan di sekitar DAS dimanfaatkan untuk keperluan pertanian dan pemukiman sebagaimana data berikut (BBWS Pemali Juana 2015):

- Hutan Tanaman Industri ( HTI ) 2477.88 Ha

- Perkebunan $198.36 \mathrm{Ha}$

- Permukiman $5861.50 \mathrm{Ha}$

- Pertanian Lahan Kering $5442.02 \mathrm{Ha}$

- Pertanian Lahan Kering Bercampur dgn Semak 6 718.14 Ha

- Sawah $749.25 \mathrm{Ha}$

Sun et al. (2012) menyatakan bahwa produksi pangan secara intensif di Cina selama lebih 2 dekade merupakan penyebab timbulnya limbah organik. Pada tahun 2007 kegiatan pertanian (produksi pangan dan peternakan) menyumbang 243 juta ton limbah organik, 163 juta ton urin, jumlah keseluruhan $\mathrm{N}$ dan $\mathrm{P}$ yang dihasilkan oleh ekskresi hewan masing-masing mencapai 1024800 ton dan 160400 ton (MEP et al. 2010). Konsentrasi TSS yang terukur meskipun melampaui baku mutu air laut untuk biota laut, namun masih jauh lebih rendah daripada yang terukur pada beberapa sungai lainya seperti Sungai Sail Pekanbaru, Riau sebesar 220 - 1556 mg/l (Suwandi et al. 2014), sungai Air Hitam Pekanbaru, Riau sebesar 220 - 516 mg/l (Suwandi et al. 2014) dan Kali Pesanggrahan sebesar 19 - $116 \mathrm{mg} / \mathrm{l} \mathrm{TSS} \mathrm{(Djoharam} \mathrm{et} \mathrm{al.} \mathrm{2018).}$

Konsentrasi nitrat yang terukur meskipun melampaui baku mutu air laut untuk biota laut, namun masih jauh lebih rendah daripada yang terukur pada bebarapa sungai lainnya di Sungai Sail Pekanbaru dengan kisaran 1.22 - $1.89 \mathrm{mg} / \mathrm{l}$ (Suwandi et al. 2014). Sungai Air Hitam Pekanbaru (1.15 - $9.89 \mathrm{mg} / \mathrm{l})$. sungai Ujung batu Jepara sebesar $0.6478 \mathrm{mg} / \mathrm{l}$ (Karil et al. 2015). Sungai Bremi Pekalongan sebesar $0.25-0.99 \mathrm{mg} / \mathrm{l}$ (Rumanti, 2014), namun lebih tinggi dari muara Sungai Tondano, Teluk Menado (Rumengan et al. 2017).

Demikian pula konsentrasi fosfat meskipun melampaui baku mutu air laut untuk biota laut, namun masih lebih rendah daripada yang terukur pada bebarapa sungai lainnya seperti di Sungai Sail Pekanbaru dengan kisaran $0.29-0.55 \mathrm{mg} / \mathrm{l}$ (Suwandi et al. 2014). Sungai Air Hitam Pekanbaru sebesar $0.65-0.87 \mathrm{mg} / \mathrm{l}$ (Suwandi et al. 2014). muara Sungai Tondano. Teluk Menado yang berkisar $0.575-1.198 \mathrm{mg} / \mathrm{l}$ (Rumengan et al. 2017). sungai Ujung batu Jepara sebesar $0.9784 \mathrm{mg} / \mathrm{l}$ (Karil et al. 2015). Sungai Bremi Pekalongan sebesar 0.23 $1.20 \mathrm{mg} / \mathrm{l}$ (Rumanti 2014).

Kedalaman dan kecepatan aliran sungai berpengaruh terhadap debit sungai. Semakin besar debit, pengenceran air sungai terhadap polutan atau kontaminan yang ada di sungai semakin besar (Irianto dan Machbub, 2012). Konsentrasi polutan berbanding terbalik dengan debit sungai. Konsentrasi total $\mathrm{N}$ dan Total $P$ berkurang dengan semakin meningkatnya debit air sungai Citarum.

TSS merupakan padatan yang tidak dapat larut di dalam air. TSS dapat mengendap apabila ukuran butirannya membesar akibat terjadinya agregasi. Jika ukuran butiran membesar, gaya gravitasi semakin meningkat. Apabila kekuatan gaya gravitasi melampaui daya dorong arus sungai, butiran akan mengendap ke dasar perairan. Oleh karena itu konsentrasi TSS di dalam air sungai sangat erat kaitannya dengan kecepatan 
arus. Hal ini ditunjukkan oleh hubungan antara konsentrasi TSS dengan kecepatan arus sangat nyata $(\mathrm{p}=$ 0.014) tetapi tidak nyata untuk kedalaman $(\mathrm{p}=0.748)$. Hubungan antara kecepatan arus $(\mathrm{X})$ dengan konsentrasi TSS $(\mathrm{Y})$ dinyatakan oleh persamaan $\mathrm{Y}(\mathrm{mg} / \mathrm{l})=110-216 \mathrm{X}(\mathrm{p}=0.008)$. Menurut persamaan regresi ini konsentrasi TSS semakin berkurang dengan meningkatnya kecepatan arus atau dengan kata lain, konsentrasi TSS semakin besar jika arus relatif tenang atau diam. Keadaan ini terjadi oleh karena pengambilan contoh air dilakukan pada saat pasang, dimana air laut mendorong air sungai masuk ke dalam ke arah hulu, sehingga terjadi penumpukan TSS pada titik sampling 3 yang arusnya paling lambat. Pada titik sampling 3 diduga terjadi pertemuan antara arus pasang dan arus sungai, sehingga konsentrasi TSS lebih tinggi di titik sampling ini.

Hasil analisis ragam menunjukkan bahwa kedalaman sungai antara titik pengambilan contoh air relatif sama atau tidak berbeda nyata, namun kecepatan arus sangat berbeda nyata. Sehingga dapat dikatakan bahwa faktor yang paling menentukan besarnya beban pencemaran TSS, nitrat dan fosfat pada sungai BKB adalah konsentrasi, lebar dan kecepatan arus sungai untuk peubah TSS, sedang untuk peubah nitrat dan fosfat hanya ditentukan oleh lebar dan kecepatan arus sungai.

Temperatur, $\mathrm{pH}$, salinitas dan oksigen terlarut dapat mempengaruhi reaksi-rekasi kimia yang terjadi di dalam air dan merupakan faktor yang dapat memodifikasi toksisitas bahan beracun yang terdapat di dalam air. Temperatur merupakan faktor yang paling berperan dalam pengaturan aktifitas fisiologis, biokimia dan life history ikan (Beitinger and Fitzpatrick 1979). Oksigen terlarut sangat penting peranannya bagi biota air. Berkurangnya oksigen terlarut di air dapat menyebabkan gangguan aktivitas respirasi bahkan menyebabkan kematian biota air, mengurangi nafsu makan dan menghambat perkembangan embrio ikan (Clark 1996). pH sangat menentukan tingkat produktivitas perairan. Air yang memiliki $\mathrm{pH}$ alkalin memiliki produktivitas yang tinggi (Moyle 1993).

Berdasarkan data kapasitas asimilasi yang diperoleh setelah memplotkan kurva konsentrasi sebagai absis dan beban pencemaran sebagai ordinat, ditetapkan bahwa beban pencemaran TSS umumnya telah melampaui kapasitas asimilasi perairan untuk terumbu karang dan mangrove, kecuali pada titik sampling 3 beban pencemaran TSS masih dibawah kapasitas asimilasi untuk mangrove. Hal ini diduga akibat arus di titik sampling 3 lebih tenang, sehingga TSS lebih banyak mengendap. Sementara beban pencemaran nitrat dan fosfat yang berasal dari sungai BKB telah melampaui kapasitas asimilasi muara sungai atau estuari. Masuknya beban pencemar yang melampaui kapasitas asimilasi suatu perairan atau badan air menyebabkan terjadinya gangguan asimilasi bahan pencemar oleh perairan/badan air, sehingga menimbulkan pencemaran air. Hal mana sejalan dengan hasil perhitungan indeks kualitas air diperoleh IKA sebesar 51.94 menunjukkan bahwa perairan muara/estuari BKB tergolong tercemar sangat berat oleh TSS, nitrat dan fosfat (Marganingrum 2012). Hasil ini sejalan dengan penelitian yang dilakukan oleh Tim Peneliti Kementerian Kelautan dan Perikanan (2015) yang menunjukkan bahwa estuari Banjir Kanal Barat telah tercemar berat atau kotor oleh TSS, nitrat dan fosfat. Air demikian ini tidak sesuai untuk berbagai kebutuhan dan butuh biaya yang sangat mahal untuk pemanfaatannya (Marganingrum 2012).

\section{SIMPULAN}

Hasil penelitian menunjukkan bahwa beban pencemaran TSS berkisar $22751.493-117256.591 \mathrm{~kg} / \mathrm{hari}$. nitrat berkisar 154.019 - $1843.323 \mathrm{~kg} / \mathrm{hari}$. dan fosfat berkisar 0 - 835.463 kg/hari. Beban pencemaran TSS, nitrat dan fosfat yang berasal dari sungai BKB pada umumnya telah melampaui kapasitas asimilasi muara sungai untuk berbagai bahan tersebut, sehingga menimbulkan pencemaran air. Indeks kualitas air (IKA) yang diperoleh sebesar 51.94 menunjukkan bahwa perairan muara/estuari BKB tergolong tercemar sangat berat oleh TSS, nitrat dan fosfat. 


\section{UCAPAN TERIMA KASIH}

Penulis menyampaikan terima kasih kepada segenap pihak yang telah membantu terbitnya artikel ini, terutama kepada pimpinan Undip dan LPPM Undip yang mendanai penelitian ini, serta reviewer yang berkenan mengoreksi dan menyempurnakan artikel ini. Demikian pula pengelola JPSL yang telah memberi kesempatan kepada kami mempublikasikan artikel pada jurnal ini

\section{DAFTAR PUSTAKA}

[APHA] American Pulic Health Association, [AWWA] American Water Works Association, [WEF] Water Environment Federation. 2012. Standards Methods for The Examination of Water And Wastewater, 22nd edition. Washington DC: American Public Health Association.

[BBWS] Balai Besar Wilayah Sungai Pemali Juana dan CV Tirta Adinugroho. 2015. Laporan Akhir Penyusunan Data Base Sungai Banjir Kanal Barat Kota Semarang. Semarang: Kementerian Pekerjaan Umum, Direktorat Jenderal Sumberdaya Air.

[BPS] Badan Pusat Statistik Kota Semarang. 2014. Semarang Dalam Angka 2013. Semarang: BPS Kota Semarang.

[BPS] Badan Pusat Statistik Kota Semarang. 2018. Semarang Dalam Angka 2017. Semarang: BPS Kota Semarang.

[BPS] Badan Pusat Statistik Kota Semarang. 2019. Semarang Dalam Angka 2018. Semarang: BPS Kota Semarang.

[KKP] Kementerian Kelautan dan Perikanan. 2015. Laporan Akhir Penyusunan Profil Pencemaran (Pesisir Kota Semarang). Direktorat Jenderal Kelautan, Pesisir dan Pulau-pulau Kecil, Satuan Kerja Direktorat Pesisir dan Lautan.

[MEP] Ministry of Environmental Protection of the People's Republic of China, [NBS]National Bureau of Statistics of the People's Republic of China, [MOA] Ministry of Agriculture of the People's Republic of China. 2010. The First National Survey of Pollution Sources Bulletin. http://www,gov,cn/jrzg/ 201002/10/content_1532174. Html.

[SNI] Standar Nasional Indonesia Nomor 06-2480-1991. 1991. Air, Metode Pengujian Kadar Nitrat dengan Alat Spektrofotometer secara Brusin Sulfat. Badan Standarisasi Nasional.

[SNI] Standar Nasional Indonesia Nomor 06-6989,31-2005. 2005. Air dan Air Limbah-Bagian 31: Cara Uji Kadar Fosfat dengan Spektrofotometer secara Asam Askorbat. Badan Standarisasi Nasional.

[SNI] Standar Nasional Indonesia Nomor 06-6989,3-2004. 2004. Air dan Air Limbah-Bagian 3: Cara Uji Padatan Tersuspensi Total (Total Suspended Solid) Secara Gravimetri. Badan Standarisasi Nasional.

[SNI] Standar Nasional Indonesia Nomor 06-7016-2004. 2004. Tata cara Pengambilan Contoh dalam rangka Pemantauan Kualitas Air pada suatu daerah pengaliran sungai. Badan Standarisasi Nasional.

Altansuukh A, and Davaa G. 2011. Application of index analysis to evaluate of water quality of the river in Mongolia. Journal of Water Resources and Protection. 3: 394 - 414.

Beitinger TL and Fitzpatrick LC. 1979. Physiological and ecological correlates of preferred temperature in fish. Am.Zool. 19(1): 319 - 329.

Boyd CE, and Tucker CS. 2012. Pond Aquaculture Water Quality Management. Springer Science and Business Media.

Clark JR. 1996. Coastal Zone management handbook. London: Lewis Publiher.

Dahuri R. 1998. The application of carrying capacity concept for sustainable coastal resources development in Indonesia. Indonesian journal of Coastal and Marine Resources Management. 1: 13-20. 
Dewi NK, Prabowo R, and Trimartuti NK. 2014. Analysis of the physicochemical quality and Heavy Metal Levels in Cyprinus carpio L. and Oreochromis niloticus L. living in Kaligarang River Semarang Biosaintifika. 6(2).

Djoharam V, Riani E dan Yani M. 2018. Analisis kualitas air dan daya tampung beban pencemaran sungai pesanggrahan di wilayah provinsi DKI Jakarta. Jurnal Pengelolaan Sumberdaya Alam dan Lingkungan 8(1): $127-133$.

Dodds WK and Smith VH. 2016. Nitrogen, phosphorus, and eutrophication in streams. Inland Waters. 6(2): $155-164$

Drewniak L, Krawczyk S, Mielnicki S, Adamska D, Sobczak A, Lipinski L, Burec-Drewniak W, and Sklodowska A. 2015. Physiological And Metagenomic Analysis Of Microbial Mats Involved In SelfPurification Of Mine Waters Contaminated With Heavy Metals. unpublished work.

Irianto EW dan Machbub B. 2012. Fenomena hubungan debit air dan kadar zat pencemar dalam air sungai (studi kasus sub DPS Citarum Hulu). http://www.scribd.com/document/101204640/fenomenahubungan-debit-air-dan-kadar-zat-pencemar-dalam-air-sungai-studi-kasus-sub-DPS-Citarum-Hulu.

Jiang B, Chen J, Luo Q, Lai J-X, Xu H, Wang Y, Yu K. 2016. Long Term Change in Water Quality and Eutrophication of China's Liujiang River. Pol. J. Environ.Stud. 2(3): 1033 - 1043.

Karil ARF, Yusuf M, dan Maslukah L. 2015. Studi Sebaran Konsentrasi Nitrat dan Fosfat di Perairan Teluk Ujungbatu. Jepara. Jurnal Oseanografi. 4(2): $386-392$.

Ketchum BH (editor). 1983. Estuaries and Enclosed Sea, Ecosystem of The World. New York: Elsevier Scientific. Amsterdam-Oxford-New York.

Marganingrum D. 2012. Penilaian mutu air sungai dengan pendekatan perbedaan hasil dari dua metode indeks. Buletin Geologi Tata Lingkungan. 23(3): 105 - 114.

Menteri Negara Lingkungan Hidup. 2004. Lampiran 3 Keputusan Menteri Negara Lingkungan Hidup Nomor 51 Tahun 2004 tentang Baku Mutu Air Laut untuk Biota Laut. Jakarta: Sekretariat Kementerian Negara Lingkungan Hidup.

Menteri Negara Lingkungan Hidup. 2010. Lampiran 2 Peraturan Menteri Negara Lingkungan Hidup Nomor 01 Tahun 2010 tentang Tata Laksana Pengendalian Pencemaran Air. Jakarta: Sekretariat Kementerian Negara Lingkungan Hidup.

Mitsch WJ and Gosselink JG. 1994. Wetlands (2nd ed.). New York: Van Nostrand Reinhold.

Moyle P. 1993. Fish: An Enthusiast's Guide. California: Berkley University of California Press.

Ostroumov SA. 2014. The theory of the hydrobiological mechanism of water self-purification in water bodies: from theory to practice.

Owa FW. 2014. Water pollution: sources, effects, control and management. International Letters of Natural Sciences. 3 (2014): 1-6.

Presiden Negara Republik Indonesia. 2001. Peraturan Pemerintah Nomor 82 Tahun 2001 Tentang Pengelolaan Kualitas Air dan Pengendalian Pencemaran Perairan. Lembaran Negara Republik Indonesia Tahun 2001 Nomor 153. Sekretaris Negara Republik Indonesia

Purnomo PW, Soedarsono P, Ain, C. 2010. Modul Praktikum Limnologi, Program Studi Manajemen Sumberdaya Perairan, Jurusan Perikanan. Universitas Diponegoro: Fakultas Perikanan dan Ilmu Kelautan.

Rumanti M. 2014. Hubungan antara Kandungan Nitrat dan Fosfat dengan Kelimpahan Fitoplankton di Sungai Bremi Pekalongan, Diponegoro. Journal of Maquares. 3(1): 168 - 176.

Rumengan I, Haeruddin, Purnomo PW. 2017. Analisis Beban Pencemaran dan Kapasitas Asimilasi di Muara Sungai Tondano, Teluk Manado. Jurnal Pengelolaan Sumberdaya Alam dan Lingkungan. 7(3): 204 210. 
Sun Bo, Zhang LX, Yang LZ, Yang FS, Norse D, Zhu Zl. 2012. Agricultural non-point source pollution in China: Causes and Mitigation measures. AMBIO. 41:370-379.

Supriyanto A. 2003. Analisis Abrasi Pantai dan Alternative Penanggulangannya di Perairan Pesisir Perbatasan Kabupaten Kendal-Kota Semarang. Tesis (tidak dipublikasi). Semarang: Program Pascasarjana, Universitas Diponegoro.

Suwandi Y, Bali S dan Itnawita. 2012. Analisis Total Fosfat, nitrat dan timbal pada sungai sail dan sungai air hitam Pekanbaru. JOM FMIPA. 1(2).

Ujianti RMD, Anggoro S, Bambang AN, and Purwanti F. 2018. Water quality of the Garang River, Semarang, Central Java, Indonesia based on the government regulation standard. Journal of Physics. 1025 (2018) 012037. doi :10,1088/1742-6596/1025/1/012037. 